\title{
Eutanásia: Conflitos e Valores na Sua Regulamentação
}

\author{
Saioron, Isabela; Saioron, Isabela; Silveira, Ana Caroline Silva da; Leão, Letícia \\ Trindade; Gonçalves, Naiane Glaciele da C.; Silveira, Rosemary Silva da; Lunardi, \\ Valéria Lerch \\ Universidade Federal do Rio Grande — isabelasaioron@gmail.com
}

Introdução: a inexistência de critérios para determinar a legalidade e a tomada de decisões frente à eutanásia pode constituir-se como fonte geradora de conflitos, tanto pelo sofrimento decorrente desta ação, quanto pela dificuldade de realizar enfrentamentos diante de um dilema ético. Objetivo: conhecer a percepção dos profissionais e acadêmicos das áreas do direito e da enfermagem acerca da regulamentação da eutanásia no Brasil. Metodologia: Trata-se de uma pesquisa qualitativa, desenvolvida com quatorze sujeitos: dois profissionais do direito, três profissionais da enfermagem, seis acadêmicos do direito e três da enfermagem de uma Universidade pública do país. a intenção de realizar esta busca na área do direito se deu pelo fato destes reunirem conhecimentos relacionados às questões legais. Já, na enfermagem, por vivenciarem questões relacionadas ao processo de terminalidade da vida e eutanásia e, ainda, por sua relação direta com o cuidado dos pacientes. Utilizou-se a entrevista como técnica de coleta de dados e a análise textual discursiva. Emergiram três categorias: Eutanásia: qual o seu significado?; a legalização da Eutanásia; a decisão frente a prática da Eutanásia. Resultados: Apesar de existir uma interpretação singular os diferentes sujeitos expressaram ideias semelhantes e referem-se à eutanásia como abreviatura da vida no intento de atingir o direito de não sofrer e de morrer suavemente frente a situações intoleráveis de dor. no que se refere a legalização e regulamentação da Eutanásia, foi possível evidenciar que apesar de não ser regulamentada no Brasil, essa é uma necessidade premente frente às diferentes questões éticas que temos vivenciado no ato de prolongar o sofrimento ou instituir medidas fúteis para manter a vida, pois muitas vezes, a eutanásia é praticada de modo sutil e até mesmo inconsciente. a regulamentação da prática da eutanásia requer a existência de critérios, pois além da existência de divergentes opiniões entre os sujeitos, não se pode tomar decisões precipitadas ao abreviar a vida dos pacientes em situações críticas, sem ao menos discutir esta decisão com outros profissionais, com o próprio paciente e seus familiares. em relação à tomada de decisões frente à prática da eutanásia, a maioria dos sujeitos referiu que os pacientes deveriam expressar esta vontade anteriormente, como acontece em outros países. É preciso ainda, a existência de uma Comissão Ética nas Instituições de Saúde, formadas por trabalhadores das diversas áreas para que possam refletir e posicionar-se. Conclusões: Evidenciou-se a necessidade de buscar um maior aprofundamento e instrumentalização para uma ação moral acerca da prática da eutanásia como uma questão ética. Essa discussão se torna importante na medida em que se considera o direito à vida e o respeito à dignidade como elementos essenciais a todos os seres humanos.

Saioron, Isabela; Saioron, Isabela; Silveira, Ana Caroline Silva da; Leão, Letícia Trindade; Gonçalves, Naiane Glaciele da C.; Silveira, Rosemary Silva da; Lunardi, Valéria Lerch. Eutanásia: Conflitos e Valores na Sua Regulamentação. In: Anais do Congresso Internacional de Humanidades \& Humanização em Saúde [= Blucher Medical Proceedings, num.2, vol.1]. São Paulo: Editora Blucher, 2014. ISSN 2357-7282

DOI 10.5151/medpro-cihhs-10662 